COMMENT

Received 7 Sep 2015 | Accepted 7 Sep 2015 | Published 13 Oct 2015 DOl: 10.1057/palcomms.2015.32

OPEN

\title{
Radical theologies
}

Mike Grimshaw ${ }^{1}$

ABSTRACT Radical theology as a field encompasses the intersections of constructive theology, secular theology, death-of-God theologies, political theologies, continental thought and contemporary culture. It expresses an inter-disciplinary engagement and approach dedicated to redefining the very terms of theology as a concept and practice. This article provides an introductory overview to a multi- and inter-disciplinary thematic collection dedicated to thinking in this area.

\footnotetext{
${ }^{1}$ Department of Sociology, University of Canterbury, Christchurch, New Zealand (e-mail: michael.grimshaw@canterbury.ac.nz)
} 
$t$ used to be social science orthodoxy that not only was religion in decline but that there was no place for theology or allied religious discussion and critique. Religion was something that could be explained-and explained away. Theology was to be relegated to seminaries and kept within very strict disciplinary boundaries. The future was to be secular-and more importantly, secularist. The humanities were more open to religion, especially within historical and literary studies, most often as a means of understanding texts and historical events. There was of course Religious Studies, an area that as a "studies" strove for disciplinary authenticity, but in intention and focus was often misunderstood by other areas in the university and the wider public. Also, the growth of Religious Studies as a post-war, Cold War field cannot be ignored, and here the study and the support of the study of religion arose often as counter to communism. Yet this was a field that was far more diverse within Religious Studies or Religion departments than many outside could ever hope or wish to understand. Politically it ranged from hard left to hard right. The areas of specialization within such departments often meant colleagues had far more in common with those in other departments than within their own. But one thing was usually a constant: there was no place for theology.

Furthermore, even if there existed a combined department, there was Theology and then there was Religion or Religious Studies and the boundaries between them were often strictly policed. The same types of demarcation tended to occur within combined programmes of Philosophy and Religious Studies; philosophy of religion was allowed but theology was usually forbidden. Therefore, even if religion was allowed, albeit often grudgingly, theology was viewed, at best, with suspicion, especially within the Anglosphere. In this I am speaking primarily of state-funded tertiary institutions. Of course, in privately endowed universities and colleges theology could be undertaken, but then most usually within the limits of faith traditions and a confessional ethos. The dominance of analytic philosophy in the Anglosphere also viewed with suspicion the claims and arguments of theology, preferring to allow, if anything, the limitations of a strictly policed philosophy of religion which was most often undertaken to serve the ends of analytic thought. This is, of course, a broad-brush caricature, but for those of us who undertook most of our academic study and training in the last century, it is one that we can understand.

\section{Towards radical theology}

However, in the twenty-first century, theology is increasingly back and making its presence felt in a number of disciplines via the influence of continental thought. It is interesting to note that the American theologian Van Harvey identified this as a possibility back in 1970, where, in reassessing what was now opened up in the wake of the 1960s Secular Theology and the Death of God he argued for a new home and possibility for theology in Religious Studies. In particular, for Harvey (1970) this included the possibility of "a new and probably non-Christian theology of some sort" being developed that is "more strictly philosophical and does not at all understand itself as a servant of a church or a tradition" (28). Referencing Victor Preller of Princeton, Harvey terms this a "meta-theology" (Harvey, 1970: 28 ) or "a genuinely secular theology" (Harvey, 1970: 29) that is to be thought, critiqued and argued in departments of Religion. This is what I term the American strand of origin of radical theology: a theology that, arising out of the American encounter with modernity, arising from secular theology and the Death of God theologies, sought to express a theology not held captive by the church. Such a radical theology aimed to express a theology of radical critique not only of the institutional expressions of religions, but also of the society where those institutions often held sway. Radical theology therefore existed and was expressed as a language and grammar of critique, a voice from within the western tradition that proclaimed a counter-narrative, a prophetical tradition of dissent.

The other strand within radical theology is the one that has risen to prominence in this century, a radical theology arising from within what can be termed continental thought, from within an intellectual history whereby non-analytic philosophy and theology intersected with each other. This is from an intellectual tradition open to the use the language of theology as a political and social counter-claim, a grammar and language that holds within it both the excess and limit of possibility. This means that "god" within such a radical theology is first and foremost a noun that operates as that uttered as a claim as to the excess and limit of possibility. A claim uttered in relation to human activity, a claim that seeks to overcome human actions of limitation and exclusion, a claim uttered against our acting inhumanly to others. In this tradition, theology continues as a necessary problem within both modernity and post-modernity, the necessary problem that holds within it a counter-narrative to the enlightenment-derived claims of the triumph of rationality, reason and logic. But also in its central claim of the necessary value of the human being, theology exists as a counter claim to the economic reductionism of capitalism and especially neoliberalism and occurs increasingly therefore as a counter-claim to the instrumentalist reduction of an uncritically technologicallytriumphalist society.

Out of these two traditions arises what can be termed radical theology, a theology that is type of nomadic mode of thinking and action, unsettled and unsettling, wandering across, within and against both institutional religion and the surrounding secular, pluralist society. Radical Theology is not a singular activity, nor is it stable, and it rejects both orthodoxy and orthopraxis. Rather it is, via the plurality of the saeculum, a plurality of theologies. Therefore, rather than being a defined body of knowledge, radical theology is an activity of intent and a hermeneutics of critique of all that taken to be normative. Radical theology is where we get, where we claim, where we demand the space, language and the tradition to talk, think, critique and re-imagine human value in a world where value is too often consigned to function and economic value. Radical theology also exists explicitly as part of a rupture and reassessment of the Western project. Radical Theology is therefore a way of writing, thinking and talking against the limitations of both secular and confessional authorities. This can be understood when we acknowledge that Radical Theology as a field encompasses the intersections of constructive theology, secular theology, death of god theologies, political theologies, continental thought and contemporary culture.

\section{Thematic collection}

Just as Rhizomic thought engages with multiplicities and counters dualistic and prescriptive approaches, this thematic collection issue offers a timely outlet for an expanding field of "breakout" radical theologies that seek to redefine the very terms of theology. This thematic collection engages with an ever-multiplying radical expression and critique by theologies that have entered or seek to enter the public sphere, arising from the continued turn to religion and especially radical theology in politics, social sciences, philosophy, theory, cultural, queer and literary studies.

All share the aim and expression of breaking out of walls previously ideologically invisible. The article collection covers the 
engagement of radical theology with culture, society, literature, politics, philosophy and the discipline of religion. Providing an outlet for those writing and thinking at the intersections of these areas with radical theology, radical theology expresses an interdisciplinary engagement and approach dedicated to redefining the very terms of theology as a concept and practice. This can be seen in the papers included in this launch of the thematic collection:

Bray (2015), in The Monstrosity of the Multitude critically engages with the issues of disability and work; Grimshaw (2015) traces a different possibility of secular theology, despite the death of God, via Gabriel Vahanian; Robbins and Crockett (2015), who we can think of as this century's "Deleuze and Guattari" of radical theology, outline Five Theses for a Radical Theology for the Future; Wigg-Stevenson (2015) brings an Ethnographic Disruption to theology; Dubilet (2015) articulates the messianic possibility of non-philosophy along with a central proclamation of justice; Kelley (2015) considers hermeneutics and genocide. Further essays in thematic collection will engage with divinations of neo-liberalism, amongst other possibilities.

Central to all radical theology is an engagement with the limits of authorities and their limits on the world. One way it does so is by talking seriously the both limits and failures of modernity. As stated, radical theology is part of a post-enlightenment critique that situates and acts versus the instrumentalism and pathology of the hegemony of the Enlightenment. Radical theology is also political in the sense that it critically engages with issues of power, participation, order and structure. Radical Theology is therefore a theology of transgression: writing and thinking within and yet against what is taken to be normative in a tradition, a hermeneutic and a culture.

This is the disruptive function of Radical Theology: as the activity that speaks within and into and against all normative culture spheres, including any rethought and re-imagined religion-or indeed any rethought secularism. Radical Theology is therefore the theology of those who recognize the hermeneutics and claims of western thought and yet speak out with the prophetic voice from the margins. Thus Radical Theology is too secular for theology, too theological for the secular, too theological for philosophy and too philosophical for theology, too social science for the humanities and too humanities for the social sciences. Against all such oppositional dualisms, Radical Theology occurs as a series of activities comprising the rearticulation of that central prophetic voice and thought from within, yet against the western tradition, that reminds us, often against our wishes, of our continually expressed roots (radix) in Judeo-Christian thought and culture.

I wish to position, deliberately broadly, a claim that religion itself is an interpretative frame that is applied to, and used to create, other interpretative frames. According to my analysis, the importance of religion is that it states "there is an alternative" and the grounding of religion in not only the human sciences but also the social sciences arises precisely because of this. We too easily choose to forget that religion is crucial for the self-definition of Modernity. For in religion's dialectic with Modernity lies the mutually counter claim: "there is an alternative". I am also always in debt to Charles Winquist's distinction between theological study and studying theology. If to study theology "treats the theological tradition as data to be learned, absorbed and comprehended" [in effect a version, I would argue, of sui generis], then to undertake theological study "means to think with the desire for a thinking that does not disappoint, to think in extremis, to ask what is real and important" (Robbins, 2003: xv-xvi).

The challenge of the problem of Radical Theology for Religious Studies is, as Jeffrey W. Robbins notes, that of "theology's insistence that knowledge is fundamentally limited by the gap between the known and the real, while at the same time driven by the desire to think the unthinkable and speak the unspeakable"(Robbins, 2003: 27). From this I position radical theology as the language, the grammar, the talk of this tension between limit and possibility and its resultant activity. Theology is what humans do in our here and now, using the language and claims of the possibility of an alternative. So a radical theologian is one who uses theology and theological language as a way of interrogating and critiquing the world we live in, but using the words and ideas as claims that exist as cultural critiques, as the claim of an alternative, not as dogmatic claims. So as the radical theologians Robbins and Crockett (2003) state regarding the role of theology in the work of Charles Winquist: "Theology was a discourse formulation that functioned to fissure other discourses by pushing them to their limits and interrogating them as to their sense and practicality" (ix) In effect radical theology continually asks of all claims to authority: What does this mean? Are you serious? How does this impact? What is the limit of this? What is its possibility? What is the alternative? In fact I want to argue that this function of radical theology, its fissuring and interrogation, results in what can be called theologyless theology and religionless religion-the difference between what theology and religion could be, and what they are. But moreso, as an activity that arises out of the prophetic heritage, the central interrogation, the central fissurring of radical theology is focussed on the difference between what the world, what humanity, what our knowledge production and practices could be-and what they are.

Therefore, out of this, arises this special collection whereby Radical Theology is positioned as the thought and discourses that hold that description and comparison cannot be undertaken without value; that an uncritical description and comparison cannot be undertaken and expressed as normative. The papers that follow all their own ways hold true to these principles. They are the expression of a claim of an alternative, the refusal to be domesticated and disciplined, the expression of the excess and limit of possibility, arising from within, yet in critical engagement with, traditions of hermeneutic knowledge.

\section{References}

Bray K (2015) The monstrosity of the multitude: Unredeeming radical theology. Palgrave Communications; 1: 15030.

Dubilet A (2015) "Neither God, nor world": On the one foreclosed to transcendence. Palgrave Communications; 1: 15027.

Grimshaw M (2015) "In spite of the death of God": Gabriel Vahanian's secular theology. Palgrave Communications; 1: 15025.

Harvey V (1970) Reflections on the teaching of religion in America. Journal of the American Academy of Religion; 38 (1): 17-29.

Kelley S (2015) Hermeneutics and genocide: Giving voice to the unspoken. Palgrave Communications; 1: 15031.

Robbins J W (2003) In Search of a Non-Dogmatic Theology. The Davies Group, Publishers: Aurora, CO.

Robbins J W and Crockett C (2003) Foreword In: Winquist C E (ed) The Surface of the Deep. The Davies Group, Publishers: Aurora, CO.

Robbins J W and Crockett C (2015) A radical theology for the future: Five theses. Palgrave Communications; 1: 15028.

Wigg-Stevenson N (2015) From proclamation to conversation: Ethnographic disruptions to theological normativity. Palgrave Communications; 1: 15024. 


\section{Additional Information}

Competing interests: The authors declare no competing financial interests.

Reprints and permission information is available at http://www.palgrave-journals.com/ pal/authors/rights_and_permissions.html

How to cite this article: Grimshaw M (2015) Radical Theologies. Palgrave Communications. 1:15017 doi: 10.1057/palcomms.2015.32. (c) (i) This work is licensed under a Creative Commons Attribution 3.0 cc) International License. The images or other third party material in this article are included in the article's Creative Commons license, unless indicated otherwise in the credit line; if the material is not included under the Creative Commons license, users will need to obtain permission from the license holder to reproduce the material. To view a copy of this license, visit http://creativecommons.org/licenses/by/3.0/ 